
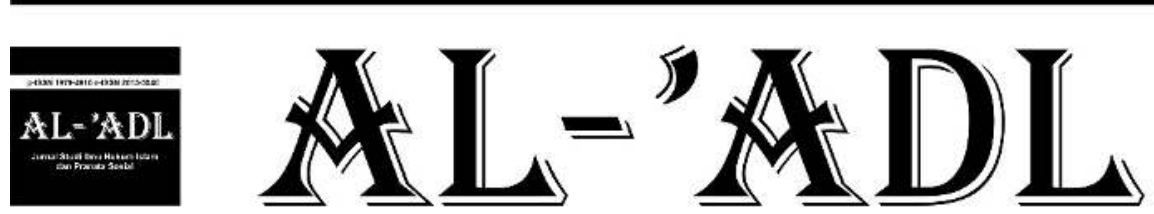

AL-'ADL

Jurnal Studi IImu Hukum Islam dan Pranata Sosial

journal homepage : ejournal.iainkendari.ac.id/al-adl

\title{
Pregnancy Married in the Perspective of Islamic Law and Five Mazhab
}

\section{Nasruddin S. ${ }^{1}$ and Sulaemang $\mathbf{L}^{2}$}

${ }^{1}$ Program Studi Ahwal Al - Syakhshiyah, Pascasarjana, Institut Agama Islam Negeri (IAIN) Kendari, Indonesia

${ }^{2}$ Program Studi Ekonomi Syariah, Fakultas Ekonomi dan Bisnia Islam, Institut Agama Islam Negeri (IAIN) Kendari, Indonesia

E-mail: nasruddinsul@gmail.com ${ }^{1} \underline{\text { sulaemangiain@yahoo.co.id }}^{2}$

\begin{tabular}{l}
\hline ARTICLE INFO \\
\hline Article History : \\
Received: 2020-10-23 \\
Accepted: 2020-10-24 \\
Published: 2020-01-27
\end{tabular}

Keywords :

Five Mazhab, Islamic

Law, Pregnancy

Marriage

\begin{tabular}{l} 
ABSTRACT \\
\hline This research discusses the issue of pregnancy \\
marriage from the perspective of Islamic Law and \\
Five Mazhab. Marriage in Islam refers to a physical \\
and mental bond, which is sacred and contains the \\
value of worship. However, adultery often occurs \\
leading to the illegal pregnancy causing the married \\
by accident. As a result, to cover up the disgrace and \\
survive, these pregnant women need to immediately \\
marry either the man who impregnated her or \\
someone else. Accordingly, whether the pregnancy \\
married is possible according to the perspective of \\
Islamic law and five mazhab, as well as the birth \\
status of the child. The Islamic Law provides legality \\
regarding the marriage of a pregnant woman on the \\
condition that she is married to a man who \\
impregnated her, in contrast, the mazhab perspective \\
indicates the difference, some allow the marriage, \\
some prohibit the action. Among those who allow it \\
is the Hanafi Mazhab, allowing men who impregnate \\
them, Shafi'i allows without any conditions and \\
Ja'fari allows them to repent first. Meanwhile, those \\
who do not allow are the Maliki and Hanbali
\end{tabular}


(C) 2020 Al-'Adl. All

rights reserved

Mazhab except with two conditions, namely
willingness to repent and waiting for the ' iddah or
waiting period. Regarding the child's family status,
Article 100 of Islamic Law, states the child's family
relationship status with the mother and the mother's
family. Meanwhile, the scholars have different
opinions, but the majority agree that children due to
adultery are given services to their mothers.

\section{A. Introduction}

Marriage for mankind is a considerably sacred occasion stipulated by the religious shari'ah. Marriage is not solely to satisfy lust but to achieve calm, tranquility, and mutual nurturing between husband and wife based on deep love and affection. ${ }^{1}$ Al-Quran has explained this goal, that in the Islamic view the concept of marriage is the concept of love and affection. ${ }^{2}$

Thus, marriage is defined as a binding legal act between a man and a woman (husband and wife) which contains the value of worship to Allah Almighty, on the one hand, and on the other, it contains civil aspects that give rise to rights and obligations between husband and wife. Islam also clearly explains the rules of marriage, however, due to a lack of deep understanding of religious norms, as well as a lack of self-preservation of existing stimuli, not a few people fall into adultery, resulting in pregnancy outside of marriage and causing various problems, either for those who do or the family. So what is the consequence of the problems that occur, to cover up disgrace and survive, the pregnant women need to marry the man who impregnated her or another man.

According to positive law, in this case, the Islamic law provides legality regarding the marriage of a pregnant woman on condition that she is married to the man who impregnated her, in contrast to the opinion of the scholars of the mazhab that some allow and some prohibit this act. Based on the problems described above, the author will examine the issue of pregnancy marriage from the perspective of Islamic Law (KHI) and the five Mazhab, as well as how the birth status of the child. This research is significantly valuable to do to increase the scientific contribution to the development of science and provide an understanding to the community about the law of pregnancy marriage and also the impact it will have on the implementation of the marriage.

This type of research is library research. The approach used is a juridical normative approach using benchmarks derived from the Qur'an and Hadith as

\footnotetext{
${ }^{1}$ Mohamad Asnawi, 2004, Nikah dalam Perbincangan dan Perdebatan, Darusaalam, Yogyakarta, p. 20.

${ }^{2}$ Kamal Mukhtar, 1993, Asas-asas Hukum Islam tentang Perkawinan, Cet. III, Bulan Bintang, Jakarta, p. 25.
} 
well as fiqh principles and the scholars, as well as positive sources of law in the form of laws and other regulations.

\section{B. Discussion}

\section{Pregnancy Marriage in the perspective of Islamic Law}

Pregnancy marriage is a marriage held between a pregnant woman and a man who impregnated her without prior legal marriage, or with another man. ${ }^{3}$ Being pregnant without marriage is an act of adultery because when a woman has sex with a man without a legal relationship between husband and wife according to positive law and Islamic law, it is called adultery. Therefore, a woman who is pregnant without marriage committed adultery. ${ }^{4}$

The provisions in Presidential Instruction Number 1 of 1991 concerning Islamic Law, Article 53 Chapter VIII concerning Pregnancy Marriage Verse which states that:

(1) A pregnant woman without getting married can marry the man who impregnates her.

(2) Marriage with a pregnant woman referred to in paragraph (1) can be carried out without waiting for the birth of her child first.

(3) Carrying out a marriage when a pregnant woman makes them not required to remarry after the child is born. ${ }^{5}$

The above statements clearly state that a pregnant woman before conducting a legal marriage can marry a man who impregnated her, there is no additional sentence in the article related to who can marry her. In the other words, no rules strictly explain the issue. Therefore, based on the provisions of the article above, it applies to pregnant women who know the man who impregnated her, because there are no other regulations that clarify the meaning of the article, so there is no specific legal rule if the one who marries is not the man who impregnated her. In line 2 of the article, it is also explained that a pregnant woman's marriage can be carried out immediately without having to wait for the child to be conceived to be born. Rather, the marriage is permissible even though the child is still in the mother's womb. Furthermore, in line 3 it is said that the marriage of a pregnant woman is legal in the eyes of the law so that when the child is born, it is no longer necessary to remarry.

The permissibility for a pregnancy marriage regulated in Article 53 paragraph 1 of Islamic law departs slightly from the compromise of customary law. The compromise which is viewed from the reality of the existence of ikhtilaf in the teachings of fiqh is connected with sociological facts, and

${ }^{3}$ Wahyu Wibisana, "Perkawinan Wanita Hamil di Luar Nikah Serta Akibat Hukumnya Perspektif Fikih dan Hukum Positif", Jurnal Pendidikan Agama Islam -Ta'lim, Vol. 15, No. 1, 2017, p. 32.

${ }^{4}$ Rahmat Hakim, 2000, Hukum Perkawinan Islam, Cet Ke 1, Pustaka Setia, Bandung, p. 87.

${ }_{5}^{5}$ Abdurrahman, 2010, Kompilasi Hukum Islam, Akademika Pressindo, Jakarta, p. 125. 
conclusions are drawn based on the istislahlm principle. Accordingly, the formulation of the Islamic Law argues that "We will earn greater impact when we allow pregnancy marriage than prohibit it". ${ }^{6}$ According to Imam Al-Gazali istislah is the benefit that is independent of the shari'ah or in other words goodness that is not touched upon whether it is true or not in the syari'at, both in general and specifically. Therefore benefit here is human reasoning. ${ }^{7}$

According to Mardani, one of the main objectives of the permissibility principle for pregnancy marriage in Article 53 Paragraph 1 of the Islamic Laws is to provide definite legal protection to unborn children. ${ }^{8}$ According to Neng Djubaidah, the theory used to make laws contained in Article 53 of Islamic law using the reception theory (Receptie Theory or Reception Theory (Christian Snouck Hurgronje) is that Islamic Law is only recognized and implemented as law if Customary Law has accepted it so that Islamic Law has its position under Customary Law) which relies on the application of Islamic Law to Customary Law, which aims to protect children or aims to make children conceived outside of marriage born in the bond of marriage. ${ }^{9}$

Based on some of the explanations above, the purpose of allowing a pregnancy marriage in Article 53 Paragraph 1 of the Islamic law is to provide benefits to humans and to maintain and provide legal certainty for the status of children born.

\section{Pregnancy Marriage According to the Five Mazhab}

\section{a. Hanafi}

The Hanafiyah Ulama argues that it is legal to marry a pregnant woman if the man who impregnated her is the one who married her ${ }^{10}$ and if the one who marries her is not the man who impregnated her, there is a lot of debate among the sect, Abu Hanifa and Muhammad believe that it is legal if it is not the man who impregnated the woman who marries her, but the man who married her should not have intercourse with a woman who married her. be his wife until the child is born. Abu Yusuf and Zafar argue that the law is not legal to marry a pregnant woman as a result of adultery with another man, because her pregnancy prohibits sexual intercourse, so the marriage contract with the pregnant woman is also prohibited. As for the arguments of Abu Yusuf and Zafar which forbid marrying a woman who is

\footnotetext{
${ }^{6}$ M. Yahya Harahap, 1999, Kompilasi Hukum Islam dan Peradilan Agama dalam Sistem Hukum Nasional, Logos Wacana Ilmu, Jakarta, p. 57.

${ }^{7}$ Jazuni, 2005, Legalitas Hukum Islam di Indonesia, Citra Aditya Bakti, Jakarta, p. 31.

${ }^{8}$ Mardani, 2016, Hukum Keluarga Islam di Indonesia, Kencana, Jakarta, p. 92.

${ }^{9}$ Neng Djubaidah, 2010, Pencatatan Perkawinan dan Perkawinan Tidak Dicatatkan, Sinar Grafika, Jakarta, p. $163-164$.

${ }^{10}$ Usman bin Ali, 1313H, Tabyin al-Haqaiq Syarhu Kanzu al-Daqaiq wa Hasyiatu alSyibli, Al-Matba'ah al - Kubra al - Amiriyah, Kairo, p. 113.
} 
pregnant from adultery and considers it a broken contract, is qiyas for a pregnancy whose lineage is fixed, 'illat that hinders the honor of the womb. The content is respected because no sin has been committed. Therefore she should not be aborted. Meanwhile, the majority of scholars of the Hanafi mazbah reject the arguments of Abu Yusuf and Zafar over the prohibition of marrying a pregnant woman from adultery with someone else. According to them, it is unacceptable that the 'illat who experiences in the subject upon which qiyas rests is the honor of the womb, but the honor of the owner of water. And this is not in the qiyas branch because there is no honor for those who commit adultery. ${ }^{11}$

The rebuttal to the rejection of the Hanafi clerics against the arguments of Abu Yusuf and Zafar is: First, those who are respected are the owners of water and content. One of the two is not superior to the other. The owner of the water is respected because the founder of the Shari'a requires iddah on his widow or wife whom she taunts for the sake of maintaining honor because he is guarded against mixing with other men's water. Second, the liberation of the uterus is not done for the honor of the first water, but the honor of the second water. ${ }^{12}$

A person cannot claim to be a child who is not his child. Likewise, he cannot free the woman's uterus, even though she is already pregnant with the male fetus who has committed adultery with her. The point of difference that is the cause of differences in opinion is that a pregnant woman will marry a woman who commits adultery according to the arguments of the Shafi'i ulama. While their argument for prohibiting sexual intercourse, if she is pregnant from someone else, this is the hadith of Ruwaifi 'ibn Tsabit Al-Ansari:

"From Abu Marzuqi from Hasany Al-Shan'ani from Ruwaifi 'ibn Tsabit AlAnsari said: I heard the Messenger of Allah, say: it is not permissible for those who believe in Allah and the Last Day, so don't pour water on other people's plants. "13 (Narrated by Abu Dawud and Imam Tirmidhi)

Intercourse is prohibited if the pregnant woman is from someone else who is not married to her because of the barrier that can disappear. Therefore it does not prevent or damage the marriage. So it can be

${ }^{11}$ Yahya Abdurrahman Al-Khatib, 2006, Fikih Wanita Hamil, Qisthi Press, Jakarta, p. 92.

${ }^{12}$ Ibid., p. 93.

${ }^{13}$ Ibn Himam and Muhammad ibn Abdul Wahid, 1997, Syarh Fath al-Qadir ma'a Syarh alInayah ala al-Hidayah li al-Babirti, Dar al-Fikr, Beirut, p. 242. 
concluded that Imam Abu Hanifah and the majority of scholars of the Hanafi say that a pregnant woman who is married to the man who impregnated her is legal, if the man who married her was not the one who impregnated her then the marriage is also legal but may not have intercourse with the child she is carrying until the child is born.

\section{b. The Maliki}

The Malikiyah scholars argue that in fact, they do not like men marrying women who are known for their ugliness, but the Malikiyah scholars also do not forbid or allow the marriage of pregnant women, even though other scholars of the school allow the marriage of a pregnant woman whether whoever marries her as long as they are still waiting for the 'iddah period. of the woman. The argument of the Maliki scholars regarding their opinion about the illegitimate marriage of a woman who commits adultery with him is the words of Ibn Mas'ud ra "if a man commits adultery with a woman, then the man marries her after that, then both of them commit adultery forever." Besides, according to Imam Malik, marriage has honor. Among his honors is that he may not be poured into the waters of adultery, ${ }^{14}$

Indeed, the Holy Prophet wanted to curse someone who wanted to intercourse with a pregnant servant, not because of it. And if the marriage occurs, the child will be cut off from his father, who has impregnated and belongs to the husband. ${ }^{15}$ Regarding the prohibition of marrying a pregnant woman, according to Imam Malik, another scholar has the same opinion as Imam Abu Yusuf who said that the two must not be married. Because if they are married, the marriage is null and void (fasid). His opinion is based on the word of Allah in Surah An - Nur/24: 3

"Men who commit adultery do not marry but women who commit adultery, or women who are polytheists; and women who commit adultery are not married but by men who commit adultery or idolatrous men, and that is haraam for those who believe."

Al-Qurtubi said the purpose of this verse is to condemn the act of adultery and consider it a bad thing, and that adultery is forbidden for those who believe. The relationship between this meaning and the previous verse is very good. It should also be noted that what Allah's word Laa Yankihu

${ }^{14}$ Yahya Abdurrahman Al-Khatib, op.Cit., p. 95.

${ }^{15}$ M. Iqbal al - Haetami, 2004, Married by Accident, Qultum Media, Jakarta, p. 123 - 124. 
means "not marrying" is not having sex. Thus, the meaning of An Nikaah in this verse is sexual intercourse. Then Allah swt returned what was being discussed to both parties so that it could provide more emphasis and affirmation. Furthermore, Allah added the division of idolatrous women and men, because polytheism is more common disobedience than adultery. ${ }^{16}$

Based on the explanation above, it can be concluded that the Malikiyah scholars think that it is not permissible to marry a woman who is pregnant, either by the man who impregnated her or by a man who did not impregnate her.

\section{c. The Shafi'i}

Imam Syafi'i agrees that pregnant marriage is legal and the law is permissible because the presence of a fetus does not damage the contract of marriage, and intercourse is legal, that is because according to Imam Shafi'i it is impossible for the baby's lineage to not be tarnished with her husband's sperm and if they are not bound by other marriages, so that is considered sahlm. ${ }^{17}$ In this case, the Shafi'i thought relies on the argument of Qs. An Nur/24:32.

"And marry those who are alone among you, and those who are worthy (married) of your male servants and your female servants. If they are poor Allah will empower them with His grace. And Allah is Vast (His gift) again for those who know"

The above argument explains that adulterers are among the unmarried group, so there is no prohibition to marry them even if they are pregnant. Because the woman is not married to another person and may have intercourse with her because the baby's nasab cannot be mixed or tainted by the sperm of her husband who did not impregnate her. Imam Abu Hanifah and Imam Syafi'i argue that marriage is considered valid because it is not tied to another person's marriage (there is no 'iddah period). The woman may also be meddled with because the child's nasab (offspring) can't be tarnished by her husband's sperm. Meanwhile, the child is not the descendant of the person who married the mother (the child outside of marriage). Abu Hanifah and Imam Syafi'i also argue that pregnant women outside of marriage have no 'iddah'. According to them, women who commit adultery are not subject to legal provisions as stipulated by syar'i,

\footnotetext{
${ }^{16}$ Shaykh Imam al-Qurtuby, 2009, Al-Jami 'Li Ahkam Al-Qur'an, trans. Ahmad Khotib,
} Cet. I, Pustaka Azam, Jakarta, p. 435 - 436.

${ }^{17}$ Abd. Rahman Ghazali, 2003, Fiqh Munakahat, Kencana Prenada Media, Bogor, p. 124. 
because 'iddah is required to maintain offspring and respect sperm. This disrespected adultery sperm makes the contract of a woman committing adultery is possible, the woman is lawful to marry and there has never been a law stipulating that it is prohibited to marry her. The woman is just not allowed to have sex until the woman gives birth. ${ }^{18}$

In the book of Majmu 'Syarah Muhazzab, Imam Nawawi states that women who are pregnant as a result of adultery can be married. ${ }^{19}$

This opinion assumes that a woman who is pregnant as a result of adultery is not subject to legal provisions as stipulated in a legal marriage according to shari'ah. Meanwhile, it is necessary to implement 'iddah because it is to maintain the purity of the nasab and respect for sperm. However, in the case of adultery, the sperm of an adulterous man is not respected, and a pregnancy that occurs outside of marriage sends his child to the mother who conceived him.

So it can be concluded that the Syafi'iyah cleric believes that it is legal to marry a pregnant woman, even though it is not the man who impregnated her.

\section{d. The Hanbali}

Hanabilah scholars argue that marrying a pregnant woman is unlawful. The marriage is not legal unless it has done two things, namely, repent and wait for the "iddah period. Ibn Qudamah said that in the time of the Holy Prophet there was a man who married a woman, when the man approached him he found that she was pregnant. This matter was put to the Prophet (s), then he separated the two and the dowry was handed over to the woman and he was bound a hundred times. This hadith was narrated by Sa'id. ${ }^{20}$ The hadith is the reason for people who say it is not legal to marry and should not associate. They oblige 'iddah because basically, they want the purity of the uterus.

Ibn Qudamah who is one of the scholars of the Hambali school said that the law of marriage for a pregnant woman because adultery should not be done when the woman is pregnant. Because according to Ibn Qadamah

${ }^{18}$ Abdurrahman al-Jaziry, 1969, Al-Fiqh Ala al-Mazahib al-Arba'ah, Juz IV, Dar al-Haya'ei al-Turats al-'Arabiy, Beirut, p. 515.

${ }^{19}$ Imam Abi Zakarya Muhyiddin bin Syarfu Nawawi, 2005, Majmu’ Syarah Muhazzab, Juz XVII, Dar-al-Fikr, Lebanon, p. 383.

${ }^{20}$ Abdullah bin Ahmad ibn Qudamah, 1985, Al-Mughni: Fi Figh al-Imam Ahmad bin Hanbal, Dar al-Fikr, Beirut, p. 601. 
that women who have intercourse outside of marriage must still undergo the 'iddah period. ${ }^{21}$

After he has finished his' iddah period, the woman is not allowed to marry because he has to fulfill the second condition, namely, repent in earnest. $^{22}$

\section{e. The Ja'fari}

Meanwhile, according to Imam Ja'far and the scholars of the Ja'fari mazhab, they believe that a woman who is pregnant is allowed to marry either the man who impregnated her or not the man who impregnated her, especially if the woman wants to repent first so that it will lead to good matters. ${ }^{23}$

\section{Nasab Status of a Born Child}

Islamic law provides provisions regarding the family status of children born outside of marriage, it is contained in Article 100 Presidential Instruction Number 1 of 1991, Compilation of Islamic Law which states that "Children born outside of marriage only have a family relationship with their mother and their mother's family". In this regard, Article 186 of the Compilation of Islamic Law states "Children born outside of marriage only have an inherited relationship with their mother and their family from their mother's shoulders".

Likewise, the scholars agree that the child due to adultery is not given to his father, but his mother. As explained by Ibn Rusyid in the book Bidayatul Mujtahid that "the scholars agree that the child due to adultery is not served by his father, except for what happened in the era of ignorance". ${ }^{24}$

The scholars agree that a legitimate child is a child born as a result of a legitimate marriage. ${ }^{25}$ But they have different opinions about the occurrence of sexual relations which makes the child a legitimate child and is served by the father (the husband of the mother);

First, according to Abu Hanifah, a valid marriage contract is solely the reason for the continuity of the child's lineage, even though after the marriage

${ }^{21}$ Chuzaimah T. Yanggo and Hafiz Anshari, 2002, Problematika Hukum Islam

Kontemporer, Logos Wacana Ilmu, Jakarta, p. 54.

${ }^{22}$ Abdullah bin Ahmad ibn Qudamah, op.Cit., p. 516.

${ }^{23}$ Muhammad Jawad Mughniyah, 1989, Fiqh al-Imam Ja'far ash-Sadiq 'Ardh wa Istidlal, Dar al-Jawad, Beirut, p. 525.

${ }^{24}$ Aladin, "Perkawinan Hami di Luar Nikah dalam Perspektif Kompilasi Hukum Islam (KHI) dan Fiqih Islam di Kantor Urusan Agama (Studi Kasus di Kota Kupang)", Masalah Masalah Hukum, Vol. 46, No. 3, Juli 2017.

${ }^{25}$ Muhammad Abu Zahrah, Al-Ahwāl as-Syakhşiyyah (ttp: Dār al-Fikr al-Arabi, nd), p. 453. 
contract the husband and wife never met so they never had intercourse because they were far apart. If the wife becomes pregnant and gives birth, the child is given service to the man who becomes the husband of the mother.

Second, according to Imam as-Shafi'i and Malik, that a child can be served by the husband of his mother if there is no obstacle between the husband and wife to meet, meaning that there is a possibility that the two of them meet and have sexual relations so that the wife becomes pregnant and gives birth.

Third, according to Ibn Taimiyyah, a child is considered a legitimate child and is given service to the husband of the mother if there is sexual intercourse between the husband and wife after the Nikahlm contract. The text must be determined that sex has occurred, not based on a contract solely.

Ibn Taymiyyah's opinion, according to Abu Zahrah, is the opinion that is considered the strongest among the other opinions and is the opinion held by the majority of scholars. ${ }^{26}$

About the length of the gestation period, the gestation period is divided into two, namely the least period of pregnancy and the longest gestation period;

\section{1) Minimal gestation period}

The minimum pregnancy period according to the agreement of the scholars is six (6) months. ${ }^{27}$ This six (6) month period is based on Surat alAhqaf (46) verse 15, that the length of the pregnancy and breastfeeding period is 30 months (tsalātsūna syahran). Whereas in Surat Luqman (31) verse 14 it is stated that the perfect breastfeeding period is two (2) years (āmain) or 24 months so that the pregnancy period is at least six (6) months.

The conditions of at least six months for a pregnancy can be explained further:

First, If a man and woman get married and get pregnant and give birth to a life and perfect life within the marriage period of fewer than six months, then the child is not sent to the man who becomes the husband of the mother. ${ }^{28}$

According to the Hanafiyyah, the minimum period for pregnancy is also six months. If a man and woman get married and the woman gives birth to a child and the marriage period reaches six months or more, then the child is given service to the man. But if the child is born in the marriage period of fewer than six months, it is handed over to the man. He may reject the child

\footnotetext{
${ }^{26}$ Ibid., p. 289.

${ }^{27}$ Muhammad Jawwād Mugniyyah, Al-Ahwaāl as-Syakhşiyyah, Dār al-'ilm li al-Malayain, tt), Beirut, p. 76 .

${ }^{28}$ Mustfa as-Siba'I, 1965, Al-Ahwaāl as-Syakhşiyyah, Juz. I, Mathba'at Jāmiah Dimsyaq, Dimsyaq, p. 288.
} 
and can also admit it as his child, but on the condition that the child is not the result of adultery. If the child is the result of adultery, the child will not be served with the boy. ${ }^{29}$

Second, If a woman is divorced by her husband and then marries another man, then she becomes pregnant and gives birth, but the time is less than six months from the marriage, then the child is given service to the first husband. But if the child is born during the marriage period of six months or more, the child is sent to the second husband of the mother.

Third. If a wife is divorced and then marries another man and gives birth in less than six months since she joined her husband in the second marriage, but exceeds the maximum pregnancy limit since she met her exhusband, then the child is not served by her ex-husband or the second husband ${ }^{30}$.

\section{2) Maximum gestation period}

The scholars have no agreement about the longest gestation period. They have different opinions. These opinions are; According to AdDhahiriyyah the duration is nine (9) months, Muhammad ibn Abdillah ibn abd al-Hakim (Malikiyyah) is one year long, Abu Hanifah specifies two years. His opinion is based on the opinion of 'Aisyah, that a child does not remain in its mother's stomach for more than two years. According to Abu Hanifah, 'Aisyah's opinion is not' Ayesha's own opinion, but she received it from the Prophet. According to Al-Laits ibn Sa'd the duration is three years, according to as-Shafi'i the duration is four years, according to Imam Malik the duration is five years, according to some Malikiyyah the length is seven years. ${ }^{31}$

According to Ibn Rushd, the above different opinions are not based on texts but are based on different events and experiences that occur. According to him, the most suitable is nine months and one year. ${ }^{32}$

\section{Conclusion}

Based on the description above, the following conclusions can be drawn: (1) the provisions of article 53 of Islamic law allow the marriage of a pregnant woman to a man who impregnated her, but there is still a chance if it is not the man who impregnated her because no specific provisions are prohibiting this; (2) The opinions of the ulama can be grouped into two,

\footnotetext{
${ }^{29}$ Imām al - A'dham Abī Han̄̄fah an-Nu'man, 1965, Al-Ahk ā $m$ as-Syar'iyyah fi al-Ahwā as-Syakhşiyyah 'Al à al-mazhab al-imām al-A'dham Abī Hanīfah an-Nu'man, Maktabat wa mathba'at Muhammad 'Alī Shabīh wa Auladih, Mesir, p. 52.

${ }^{30}$ Ibid., p. 77.

${ }^{31}$ Mustfa as-Siba'i, op.Cit., p. 402.

${ }^{32}$ Muhammad Abu Zahrah, op.Cit., p . 452.
} 
namely those who allow and some do not. Among those who allow it is the Hanafi school, allowing men who impregnate them, Shafi'i allows without any conditions and Ja'fari allows them to repent first. Meanwhile, those that do not allow are the Maliki and Hanbali Mazhab except with two conditions, namely willingness to repent and waiting for the " $i d d a h$ period.

Regarding the child's family status, Article 100 of Islamic law states the child's family relationship status with the mother and the mother's family. Meanwhile, the scholars have different opinions, but the majority agree that children due to adultery are given services to their mothers. The gestation period agreed by the ulama is that the earliest gestational age is six months if the marriage is more than six months later the child is born, then the child has a nasab relationship to the father, if it is less than six months then the text is linked to the mother.

The provisions of Article 53 of the Islamic law concerning Pregnancy Marriages can provide legal certainty for the status of children born as legitimate children from legal marriage, then this pregnant marriage is also carried out to maintain family honor and can also cover up disgrace.

But on the other hand, the provisions of Article 53 of Islamic law still have a gap to be used as the legalization of adultery. Therefore, it is necessary to suggest that it does not appear to legalize adultery, the existence of the provisions of Article 53 also needs to be accompanied by the making of other provisions or regulations that can prevent adultery. For example, making regulations that contain sanctions that can provide a deterrent effect for adulterers, so that they can have a positive impact on others so they don't commit adultery.

\section{References}

\section{Book}

Abdurrahman, 2010, Kompilasi Hukum Islam, Akademika Pressindo, Jakarta.

Al - Haetami, M. Iqbal, 2004, Married by Accident, Qultum Media, Jakarta.

Al - Jaziry, Abdurrahman, 1969, Al-Fiqh Ala al-Mazahib al-Arba'ah, Juz IV, Dar al-Haya'ei al-Turats al-'Arabiy, Beirut.

Al - Khatib, Yahya Abdurrahman, 2006, Fikih Wanita Hamil, Qisthi Press, Jakarta. Al - Qurtuby, Shaykh Imam, 2009, Al-Jami 'Li Ahkam Al-Qur'an, trans. Ahmad Khotib, Cet. I, Pustaka Azam, Jakarta.

Ali, Usman bin, 1313H, Tabyin al-Haqaiq Syarhu Kanzu al-Daqaiq wa Hasyiatu al-Syibli, Al-Matba'ah al - Kubra al - Amiriyah, Kairo.

An - Nu'man, Imām al - A'dham Ab̄̄ Hanīfah, 1965, Al-Ahk ā m as-Syar'iyyah $f i$ al-Ahwā as-Syakhşiyyah 'Al à al-mazhab al-imām al-A'dham Abì Hanīfah an-Nu'man, Maktabat wa mathba'at Muhammad 'Alī Shabīh wa Auladih, Mesir. 
As - Siba'i, Mustfa, 1965, Al-Ahwaāl as-Syakhşiyyah, Juz. I, Mathba'at Jāmiah Dimsyaq, Dimsyaq.

Asnawi, Mohamad, 2004, Nikah dalam Perbincangan dan Perdebatan, Darusaalam, Yogyakarta.

Djubaidah, Neng, 2010, Pencatatan Perkawinan dan Perkawinan Tidak Dicatatkan, Sinar Grafika, Jakarta.

Ghazali, Abd. Rahman, 2003, Fiqh Munakahat, Kencana Prenada Media, Bogor.

Hakim, Rahmat, 2000, Hukum Perkawinan Islam, Cet Ke 1, Pustaka Setia, Bandung.

Harahap, M. Yahya, 1999, Kompilasi Hukum Islam dan Peradilan Agama dalam Sistem Hukum Nasional, Logos Wacana Ilmu, Jakarta.

Himam, Ibn and Muhammad ibn Abdul Wahid, 1997, Syarh Fath al-Qadir ma'a Syarh al-Inayah ala al-Hidayah li al-Babirti, Dar al-Fikr, Beirut.

Jazuni, 2005, Legalitas Hukum Islam di Indonesia, Citra Aditya Bakti, Jakarta.

Mardani, 2016, Hukum Keluarga Islam di Indonesia, Kencana, Jakarta.

Mughniyah, Muhammad Jawad, 1989, Fiqh al-Imam Ja'far ash-Sadiq 'Ardh wa Istidlal, Dar al-Jawad, Beirut.

Mugniyyah, Muhammad Jawwād, Al-Ahwaāl as-Syakhşiyyah, Dār al-'ilm li alMalayain, $\mathrm{tt})$, Beirut.

Mukhtar, Kamal, 1993, Asas-asas Hukum Islam tentang Perkawinan, Cet. III, Bulan Bintang, Jakarta.

Nawawi, Imam Abi Zakarya Muhyiddin bin Syarfu, 2005, Majmu' Syarah Muhazzab, Juz XVII, Dar-al-Fikr, Lebanon.

Qudamah, Abdullah bin Ahmad ibn, 1985, Al-Mughni: Fi Fiqh al-Imam Ahmad bin Hanbal, Dar al-Fikr, Beirut.

Yanggo, Chuzaimah T. and Hafiz Anshari, 2002, Problematika Hukum Islam Kontemporer, Logos Wacana Ilmu, Jakarta.

Zahrah, Muhammad Abu, Al-Ahwāl as-Syakhşiyyah (ttp: Dār al-Fikr al-Arabi, nd).

Journal

Aladin, "Perkawinan Hami di Luar Nikah dalam Perspektif Kompilasi Hukum Islam (KHI) dan Fiqih Islam di Kantor Urusan Agama (Studi Kasus di Kota Kupang)", Masalah - Masalah Hukum, Vol. 46, No. 3, Juli 2017.

Wibisana, Wahyu, "Perkawinan Wanita Hamil di Luar Nikah Serta Akibat Hukumnya Perspektif Fikih dan Hukum Positif", Jurnal Pendidikan Agama Islam-Ta'lim, Vol. 15, No. 1, 2017. 